\title{
Design, implementation, and evaluation of a precede-proceed model-based intervention for oral and dental health among primary school students of Rafsanjan city: a mixed method study
}

\author{
Mohtasham Ghaffari \\ Shaheed Beheshti University of Medical Sciences \\ Sakineh Rakhshanderou \\ Shaheed Beheshti University of Medical Sciences \\ Mostafa Nasirzadeh ( $\nabla$ mnasirzadeh13@rums.ac.ir) \\ Rafsanjan University of Medical Sciences https://orcid.org/0000-0003-0934-4697 \\ Leili Mazar \\ Rafsanjan University of Medical Sciences
}

Research article

Keywords: Oral and Dental Health, Brushing, PRECEDE-PROCEED Model, Intervention, Primary Schools' Students

Posted Date: August 19th, 2020

DOl: https://doi.org/10.21203/rs.3.rs-42178/v1

License: (1) This work is licensed under a Creative Commons Attribution 4.0 International License. Read Full License 


\section{Abstract \\ Background}

Oral and dental health has a significant impact on public health as well as the quality of life among individuals and families. This study aims to design, implement, and evaluate an intervention based on the PRECEDE-PROCEED model for oral and dental health among primary school students in Rafsanjan city, Southern Iran.

\section{Methods}

In this exploratory sequential study, predisposing, enabling, and reinforcing factors related to oral and dental health were identified using 39 semi-structured interviews with stakeholders. In the quantitative section, the training program consisted of six sessions for students (250 students) with a brushing session, three sessions for parents, and two sessions for teachers of the target group with lectures, questions and answers, role playing, practical demonstration, and the explaining of related experiences. Data were analyzed by SPSS version 18.0 using Mann-Whitney, Wilcoxon, and chi-squared tests at the significance level of 0.05 .

\section{Results}

In the qualitative section, seven predisposing factors, five enabling factors, and two reinforcing factors were identified. A training program based on the PRECEDE-PROCEED model was found to be effective in increasing the mean scores of the above constructs and the students' brushing behavior $(P<0.001)$.

\section{Conclusion}

Based on the results, the use of a PRECEDE-PROCEDE-based planning and participation model is suggested for identifying the factors related to oral and dental health behavior and also for designing, implementing, and evaluating evidence-based interventions.

\section{Background}

Oral and dental health has a significant impact on public health as well as the quality of life among individuals and their family $[1,2]$. The World Health Organization defines oral and dental health as " a person's status being free from any acute and chronic diseases in the mouth, teeth, face, and throat, which limit their capacity for nutrition, smile, speech, as well as mental and social health" [3].

About $99 \%$ of people develop dental caries throughout their lives, and around $37 \%$ of their teeth are destroyed due to caries [4]. Oral and dental diseases have been the most common diseases in humans, especially in children [5], with one out of every four preschool children in the United States suffering from tooth decay [6]. The latest results from oral and dental examinations of children aged 3 to 6 show that Iranian children pass their 3-year-old age with about 2 decayed primary teeth, and their 6-year-old age with 5 decayed primary teeth [4].

Various barriers have been reported to oral and dental health among children, including high costs, low self-efficacy, fear, false beliefs about primary teeth repair, lack of cooperation and time for healthcare issues, lack of knowledge, and having a wrong attitude towards oral and dental health [7-9]. Nutritional misbehavior in children, such as high sugar consumption, lack of dairy consumption, and the noninternalization of habits, such as being reluctant to brush and use dental floss lead to a high incidence of caries [10, 11]. The household's economic status [5] as well as the family's high education level promote children's oral and dental health [12, 13].

Children's oral and dental health is influenced by parental behavior; in addition, the interaction between family members has a positive impact on children's perception of oral and dental health [14]. Children's educational performance is highly influenced by their oral and dental health. Thus, children with poor oral and dental health are 12 times more likely than children with good oral and dental health to have restricted days, such as absenteeism [15]

Education is one of the strategies for the prevention of oral and dental diseases; hence, to achieve encouraging results, education must be principled and based on behavioral change patterns and theories [16]. The PRECEDE-PROCEED model is a planning, participatory, and community-based model widely used in planning and changing behavior. This model was introduced by Green et al. and has eight stages in two parts [17], including four planning stages, one implementation stage, and three evaluation stages. The PRECEDE part of this model 
stands for predisposing, reinforcing, and enabling constructs in terms of educational diagnosis and evaluation, which has an educational aspect. The PROCEED section focuses on health promotion aspects, including policies, regulations, and organizations in environmental and educational development. This model examines the causal relationship in the analysis of a health problem, but it does not measure the relationship between cause and effect and provides a clear framework for developing a behavior change plan [18].

Due to the failure to achieve WHO's goals for children's oral and dental health, this study aims to design, implement, and evaluate an intervention based on the PRECEDE-PROCEED model for oral and dental health among primary school students in Rafsanjan city.

\section{Methods}

\section{Study setting and participants}

The present study is an exploratory sequential study consisting of two qualitative and quantitative parts conducted in 2016-2017 over a 15 -month period. In the qualitative section, a sample of 39 volunteers, including dentists, health education and promotion professionals, parents and teachers, as well as school health educators participated through purposeful sampling, a semi-structured interview was conducted to explain predisposing, enabling, and reinforcing factors related to the priorities identified at the third stage, which were analyzed by content analysis. In the quantitative section, the target group consisted of 250 students $(n=122$ in the intervention group and $\mathrm{n}=128$ in the control group) studying in the primary school second grade in Rafsanjan city, who were selected by random sampling from 4 schools.

\section{Data collection and measures}

Data collection was done using the tool developed at the fourth stage of the model. The validity of the tool was evaluated based on 11 experts' opinions as well as the content validity index and ratio. In addition, its reliability was assessed by a test-retest method, with its Cronbach's alpha coefficient confirmed (Additional file 1).

\section{The implementation strategy}

Based on the stages of the model, at the stages one, two, and three, using literature review, scholarly resources and dissertations, as well as a group discussion with mothers, the importance of oral and dental health was explained, and the major index influencing the quality of life associated with oral and dental health was determined. In addition, the major behavioral factor influencing that index was identified. Next, the predisposing, enabling, and reinforcing factors associated with that factor were identified. In order to better explain the data, a semi-structured interview (the qualitative research) was conducted with stakeholders, the instrument constructs were formulated [Table 1], and the pretest was done on the target group. After analyzing and identifying the executive factors, an intervention program, consisted of six sessions for students with a brushing session, three sessions for parents, and two sessions for teachers and health educators in 35 days, with the duration of each session being 45 to 60 minutes, was run. In addition, the post-test was conducted three months after the intervention. The training program included lectures, questions and answers, role playing, practical demonstration, and explaining related experiences. At the end of the program, all students were given a folder, a CD, a training booklet, a toothbrush, and a toothpaste as gifts.

\section{Statistical analyses}

Data were analyzed by SPSS version 18.0 using Mann-Whitney, Wilcoxon, and chi-square tests at the significance level of 0.05 .

\section{Results}

At the social assessment stage, the impact of oral and dental health on the quality of life in children and their families was assessed in different aspects based on the study of 13 theses, 26 Persian articles, 54 English articles, 12 books, other scientific resources, and a group discussion with 9 stakeholders (mothers with children aged 6-12 and dentists). It was found out that poor oral and dental health affects people's physical, mental, social, and economic quality of life [Table 2]. In the epidemiological, behavioral, and environmental assessment (phase 2), the major index related to the quality of life, in terms of oral and dental health, was the number of decayed, missing (extracted), and filled teeth (DMFT), and the most important of which was dental caries. Next, behavioral and non-behavioral factors were identified [Table 3] based on the review of 9 theses, 36 Persian articles, 39 English articles, 8 books, other scientific resources, such as the World Health Organization, and a group discussion with 9 stakeholders (mothers with children aged 6-12 and dentists). In addition, the major influential behavioral factor was determined to be brushing behavior based on the opinions of a 14 health education professionals and dentists on the basis of decision-making matrix, with two criteria of importance and variability. 
In phase three (educational and ecological assessment), predisposing, enabling, and reinforcing factors associated with brushing behavior were identified based on the study of 7 theses, 26 Persian articles, 21 English articles, books, scientific sites and documentations, and a group discussion with 9 stakeholders (mothers with children aged 6-12 and dentists). Next, a qualitative study was designed aimed at better explaining the data, and semi-structured interviews were conducted with 39 stakeholders, including dentists, health education and promotion specialists, parents, teachers, and school health educators. Accordingly, the major factors affecting tooth-brushing behavior were identified, and after adjusting them to the findings of the first part of this phase, the major predisposing, enabling, and reinforcing factors associated with brushing behavior were identified.

After adjusting the findings of the qualitative section to those of the quantitative one, the research tool was formulated, face and content validity was assessed by 10 experts, and reliability was assessed by a test-retest estimate in 57 persons at a 14-day interval, and the final tool was designed [Table 1].

In the fourth phase, a session was held at the office of the head of Rafsanjan Administration of Education, and the program was explained to the principals of the selected schools. Then, a coordination session was held separately at each school, all resources and facilities were reviewed, and pre-test was done. The results of the pre-test were analyzed, an intervention program was formulated, a coordination session with school administrators was re-arranged, and the method of implementing the intervention program was explained.

An intervention program was run based on the findings from previous steps among students ( 6 training sessions and one session for brushing) aimed at promoting students' knowledge, attitude, and practice in terms of brushing. The program included lectures, questions and answers, the explaining of related experiences, practical demonstration, and role playing in learning areas and educational goals, the use of educational media, such as short videos, posters, and educational folders. Three sessions for parents and two sessions for teachers and school health educators were held aimed at enhancing their collaboration and gaining their support for sustaining students' behavior. Then, impact assessments were carried out, based on the designed method, among the students three months after the intervention. In addition, leaflets, CDs, educational folders, toothbrushes, and toothpastes were distributed among the students as gifts.

In the brushing session, according to the correct brushing method at the last session using practical demonstration, the role-playing method, and the use of moulage, the school water supply was used, and brushing was performed in groups of 5 to 7 individuals, with the brushing behavior of each student evaluated and necessary trainings provided. The purpose of this session was to remove some barriers, such as embarrassment and low self-efficacy in some students. In this session, the school's health educator brushed with the students, thereby encouraging them to grow enthusiasm.

In the beginning of the study (phase 1) until the completion of the intervention program (the implementation phase), all activities were planned in the Gantt chart. This program was scheduled for a 12-month period, and process evaluation was carried out and reported for each activity. To do so, activities carried out at each stage were reviewed by the type of activity, its scheduling, and its implementation method, with necessary corrections made. The important point in the evaluation was the increase in the time assigned to the interviews, which were planned over two months, but they took three months due to the sampling problems. In the end, it took 12 months for this study to complete the intervention and 3 months to evaluate the effect.

According to the impact assessment results, the mean age of the intervention group and that of the control group was $10.77 \pm 1.01$ and $10.98 \pm 0.88$, respectively. About $49 \%$ and $47 \%$ of the students in the intervention and control groups were girls, respectively. The results of the independent t-test and the chi-square test showed no significant difference in the variables of age, gender, parental education, parental occupation, family income, as well as oral and dental health status between the two groups $(P>0.05)$. After implementing the intervention program, a significant difference was observed $(P<0.001)$ in the mean score and standard deviation of knowledge, attitude, perceived susceptibility, perceived severity, perceived benefits, perceived barriers, self-efficacy, perceived behavioral control, subjective norms, motivation to comply, observational learning, brushing skills, social support and reinforcement, as well as the behavioral intention of brushing in the intervention group members. In addition, the results indicated the impact of the intervention program on all predisposing, enabling, and reinforcing factors as well as proper brushing behavior [Tables 4 and 5].

In this study, due to the time constraints of the thesis, changes made to oral and dental health indices, such as DMFT, as well as the related outcomes were not evaluated. In addition, according to the experts in the qualitative research, behavioral preferences of children, such as brushing outside the toilet, having a colorful and attractive toothbrush, being able to choose toothbrushes and toothpastes, and brushing with parents must be taken into consideration.

\section{Discussion}


Inappropriate oral and dental health adversely affects various aspects of the quality of life in children and their families. Among the physical consequences of this condition, one could refer to the incidence of a variety of diseases, growth retardation, sleep disorders, speech and learning impairments, daily work disruption, and the like. Among the psychological effects of this condition, one could allude to reduced self-esteem, anxiety, stress, depression, restlessness, dissatisfaction with one's mental image and public appearance, lack of emotional health, as well as the feelings of humiliation, shame, and embarrassment. In addition, among its social consequences, one can mention impaired social interaction, lack of social participation, such as participation in recreational activities, social exclusion and labeling, failure to attend school and work, impaired occupational and academic performance, and an adverse impact on the quality of family life. Among the economic consequences of this condition, one could refer to the imposing of costs and exerting of an impact on family economy [19-21]. Similar to other studies, DMFT was the major index of the quality of life affecting oral and dental health [2224].

At the beginning of the study, $35.2 \%$ of the students brushed their teeth less than twice a day, and $64.7 \%$ of them brushed their teeth at least twice a day. In the study of Goodarzi et al, $44.7 \%$ of students brushed their teeth less than twice a day, and in the study of John et al, $31.5 \%$ of students brushed their teeth at least twice a day $[25,26]$. After the educational intervention, $96.6 \%$ of the students brushed their teeth at least twice a day, indicating an improvement in their brushing performance through education.

The major predisposing factors of brushing behavior included demographic characteristics, knowledge, attitude, perceived susceptibility, perceived severity, perceived benefits, subjective norms, observational learning, and motivation to comply.

Knowledge, as the first step in the behavior change process, could play a key role in this process. The major weaknesses of the students in terms of awareness were the lack of knowledge of negative consequences (lack of awareness of psychological, psychological, and social consequences, such as decreased self-esteem, embarrassment, and losing friends), not meeting oral and dental health requirements, and the presence of symptoms of dental caries. Among the students' wrong attitudes, one could refer to the lack of belief in the brushing method and benefits of toothpastes. Holding a group discussion, answering questions about the complications and symptoms of dental caries as well as improper oral and dental health, and also extracting and correcting some of the wrong attitude and beliefs led to an increase in the mean score of these constructs in the intervention group. In the study of Babaee et al. on students aged 12-14 and in that of Sanadhya et al. on students aged 12-15, oral and dental health education improved the mean score of students' knowledge [27, 28]. In the study of Shirzad et al. an educational intervention could change the attitude of mothers and teachers towards students' brushing [29].

In the present paper, by informing the students on the positive consequences of proper oral and dental health behavior as well as the negative consequences in different aspects of the quality of life, their perceived susceptibility and perceived severity improved. Peyman and Pourhaji in their study, provided an educational program based on the Health Belief Model on oral and dental health behavior, which significantly increased the scores of perceived susceptibility, perceived severity, and perceived benefits in primary school students [30]. Subjective norms are the amount of social pressure perceived by an individual to perform a behavior; in other words, it is the reflection of the social influence on the individual, along with motivation to comply, which can cause to behavioral intention [18]. After the intervention program, the difference between the mean score of subjective norms and that of motivation to comply was significant between the two groups, indicating that the intervention program increased the mean score of these two constructs. In the study by Naseri-Salahshour et al. an oral and dental health promotion program aimed at preventing early dental caries in schoolchildren led to a significant increase in subjective norms after educational intervention [31].

The major enabling factors associated with brushing behavior included perceived barriers, self-efficacy, perceived behavioral control, and the ability to brush or brushing skills.

Gum bleeding and numbness were the major perceived barriers in the present study. The mean score of perceived barriers decreased significantly by a group discussion, questions and answers, as well as the explaining of the importance of oral and dental health and its effects on general health. In the study of Hajimiri et al. oral and dental health education in mothers of children aged 3-6 in terms of tooth decay, based on the Health Belief Model in Zanjan city, significantly reduced the perceived barriers score [32]. Such a statistically significant difference was also observed in the study of Shamsi et al. on pregnant women in Arak [33].

The concept of self-efficacy in the present study was students' confidence in the ability to correct brushing behavior after each meal, between meals, and even after eating sweets. The mean score of self-efficacy after the intervention was $95.73 \%$, which was significantly higher than that before the intervention. Consistent with the present study, in the study of Ghorbaniet al. the mean score of the selfefficacy of oral and dental health-promoting behavior increased significantly after an educational intervention [34]. According to the results of some studies, poor self-efficacy among students regarding oral and dental health care behavior is one of the main causes of 
tooth decay and loss $[35,36]$. In another study, an increase in self-efficacy in oral and dental health behavior encouraged parents to arrange preventive dental visits for their children [37].

In the present study, perceived behavioral control was defined as the students' ability to display brushing behavior in situations, such as on trips, during an illness, in the state of boredom, when attending school, or when not having a toothpaste. The intervention program was shown to be effective in promoting their ability. Makvand et al. developed an effective oral and dental health interventional program to enhance perceived behavioral control in mothers of children aged 1-2 [38].

In the present study, the mean score of the brushing skill was $47.2 \%$ before the intervention. The percentage of this construct was $89.3 \%$ after the intervention, which was significantly higher than that before the intervention. In the study of Levin et al. the intervention program significantly increased the brushing skill from $26.1-87.7 \%$ [39].

In the present study, the students' behavioral intention scores increased significantly after the educational intervention. In the study by Ebrahimipour et al. oral and dental health education based on the theory of planned behavior increased the behavioral intention score of pregnant women from $17.3 \pm 2.5$ to $21.4 \pm 2$ [40]. Behavioral preferences were the major effective variables in displaying brushing behavior, so it is suggested that parents consider children's behavioral preferences.

The most important reinforcing factors identified in this study were social support and social reinforcement. By holding training classes for parents, teachers, and school educators, we sought to guide, assist, remind, and encourage the students to brush their teeth on a regular basis. In this study, due to time constraints, outcome evaluation was not carried out, so it is suggested that other researchers in this field make this type of evaluation.

\section{Conclusions}

The major predisposing factors identified in this study were knowledge, attitude, perceived susceptibility, perceived severity, perceived benefits, subjective norms, observational learning, and motivation to comply. Constructs, such as perceived barriers, proper brushing skills, perceived behavioral control, and behavioral preferences were the enabling factors. In addition, the constructs of social reinforcement and social support were the reinforcing factors based on the findings of the qualitative part of the study. According to the results of the study, an intervention program based on the community-based participatory PRECEDE-PROCEED planning model was effective in promoting tooth-brushing behavior, as well as predisposing, enabling, and reinforcing factors. Therefore, considering the importance of planning and its role in the effectiveness of intervention programs, it is suggested that participatory planning patterns such as, the PRECEDE-PROCEED model, be used in designing intervention programs.

\section{Abbreviations}

PRECEDE: Predisposing, Reinforcing and Enabling Constructs in Educational Diagnosis and Evaluation; PROCEED: Policy, Regulatory, and Organizational Constructs in Educational and Environmental Development

\section{Declarations}

\section{Ethics approval and consent to participate}

This study, derived from the results of the collaborative research project between the Vice Chancellors for Research and Technology at Rafsanjan University of Medical Sciences (Code 350) and Shahid Beheshti University of Medical Sciences (Code 8555) and it was approved by Ethics Committee of Rafsanjan University of Medical Sciences (NO: IR.RUMS.REC.1395.42). Written informed consent were obtained from all participants' parents and all interviews were audiotape and transcribed with participant's consent.

\section{Consent for publication}

Not applicable.

\section{Availability of data and materials}

The datasets generated and/or analyzed during the current study are not publicly available but are available from the corresponding author on reasonable request.

\section{Competing interests}


The authors declare that they have no competing interests.

\section{Funding}

The present study financially supported by the Vice Chancellery for Research and Technology of Rafsanjan University of Medical Sciences and Shahid Beheshti University of Medical Sciences. The funders had no role in the study design, data collection, data analysis, data interpretation and writing the manuscript or the decision to submit for publication.

\section{Authors' contributions}

MG and SR and MN conceptualized, designed and managed the study. MN Performed the study. MG performed the data analysis. MN and LM were involved in drafting the manuscript. MG and SR critically revised the manuscript for important intellectual content. All authors read and approved the final manuscript.

\section{Acknowledgements}

The authors would like to express their appreciation to the Rafsanjan and Shahid Beheshti University of Medical Sciences authorities, the Ministry of Education, teachers and principals, and students who contributed on this research.

\section{References}

1. AbdAllah EA, Metwalli NE, Badran AS. Effectiveness of a one-year oral health educational and preventive program in improving oral health knowledge and oral hygiene practices of a group of Autistic Egyptian children and their caregivers. Future Dental Journal. 2018. doi:10.1016/j.fdj.2018.02.001.

2. Ghaffari M, Rakhshanderou S, Nasirzadeh M, Asadpour M. Oral health behaviors and related quality of life among 12 years old rafsanjan children, 2017-18. J. Kerman Univ. Medical Sci. 2019;26:420-9.

3. World Health Organization. Oral health, key facts. https://www.who.int/news-room/fact-sheets/detail/oral-health. Accessed 3 Apr 2019.

4. Goodarzi A, Tavaffian SS, Heidarnia AR, Ziaoddini H. Health literacy and oral health in primary school students of district of 14 in Tehran, Iran. Mil Caring Sci. 2016. doi:10.18869/acadpub.mcs.2.4.229.

5. Esmailikia M, Gholami A, Abedzadeh MS, Sayehmiri K, Ghazanfari Z. Predict of oral health status of 3-6 years old children of Ilam: based on health belief model. J Ilam Uni Med Sci. 2016;24:49-58.

6. Mattheus D. Efficacy of Oral Health Promotion in Primary Care Practice during Early Childhood: Creating Positive Changes in Parent's Oral Health Beliefs and Behaviors. Oral Health Dent Manag. 2014;13:316-9.

7. Shirzad M, Taghdisi MH, Dehdari T, Abolghasemi J. The Effect of Educational Intervention in Changing Mothers' Attitudes, Perceived Self-Efficacy and Perceived Barriers Regarding Oral Health of Preschool Children. Iran J Health Educ Health Promot. 2015;3:181-7.

8. Ghaffari M, Nasirzadeh M, Rakhshanderou S, Ramezankhani A. Some of the Strongest Predisposing Factors on the Behavior of Tooth Brushing among Iranian School Age Children. Int J Pediatr. 2017. doi:10.22038/ijp.2017.22660.1892.

9. Ghaffari M, Nasirzadeh M, Rakhshanderou S, Ramezankhani A. Unacceptable status of oral and dental health-related knowledge among Iranian primary school students. Biosci Biotechnol Res Commun. 2017;10:260-6.

10. Keikhaee R, Rakhshani F, Izadi S, hashemi Z. Survey of oral health behaviors and its associated factors in female students of primary schools in Zabol based on health belief model. Journal of Zabol University of medical sciences health services. 2012;4:33-41. [Persian].

11. Nishide S, Yoshihara T, Hongoud H, Kanehirad T, Yawakaa Y. Daily life habits associated with eveningness lead to a higher prevalence of dental caries in children. J Dent Sci. 2019. https://doi.org/10.1016/j.jds.2019.01.015.

12. Matsuo F, Sato S, Moriyama M. The effect of parents' oral health behaviors on children and mutual communication. Pediatr Dent J. 2016. doi:10.1016/j.pdj.2016.09.002.

13. Kasmaei P, Amin Shokravi F, Hidarnia A, Hajizadeh E, Atrkar RZ. Survey of predictive factors on brushing behavior according to the three main motivational constructs among female students of primary schools. Journal of Guilan University of medical sciences. 2014;23:16-22.

14. Kabiry B, Shakerinejad G, Karami KB, Angalli KA. The Effect of Training on Students' Oral and Dental Health Behaviors and Health Belief Model Constructs. Sadra Medical Sciences Journal. 2017;2:327-38. [Persian]. 
15. Guarnizo-Herreño CC, Lyu W, Wehby GL. Children's Oral Health and Academic Performance: Evidence of a Persisting Relationship over the Last Decade in the United States. Pediatrics. 2019. doi:10.1016/j.jpeds.2019.01.045.

16. Safari M, SHojaei zadeh D, Gofrani F, Heidarnia A, Hajipakpour A.Theories, models and health education and promotion. Asar Sobhan Publications; 2014. p. $35-8$.

17. Zareban E, Ezadirad H, Adineh HA, Health Educational theory and model. Tehran. Modal Science and technology; 2018. P. 53-65.

18. Glanz K, Rimer BK, Viswanath K. Health behavior and health education: theory, research, and practice: John Wiley \& Sons; 2015.

19. García-Pérez Á, Irigoyen-Camacho ME, Borges-Yáñez SA, Zepeda-Zepeda MA, Bolona-Gallardo I, Maupomé G. Impact of caries and dental fluorosis on oral health-related quality of life: a cross-sectional study in schoolchildren receiving water naturally fluoridated at above-optimal levels. Clin Oral Investig. 2017. doi:10.1007/s00784-017-2079-1.

20. Karki S, Päkkilä J, Laitala ML, Humagain M, Anttonen V. Influence of dental caries on oral health-related quality of life, school absenteeism and school performance among Nepalese schoolchildren. Community Dent Oral Epidemiol. 2019. doi:10.1111/cdoe.12485.

21. Nilchian F, Jabbarifar SE, Larijani M, Navaei H. Evaluation of the impact of children's oral health on their family quality of life in Amol, Iran. J Isfahan Dent Sch. 2013;8(7):662-8.

22. Goodarzi A, Heidarnia A, Tavafian SS, Eslami M. Evaluation of decayed, missing and filled teeth (DMFT) index in the 12 years old students of Tehran city. Iran Braz J Oral Sci. 2019. doi:10.20396/bjos.v17i0.8654061 [Persian].

23. Marasouli P, Mohammadi Khoshrou M, Hoseinzadeh M, Niknejad E. Survey of dmft and dmft indices in urmia orphanages in 6-18year-old individuals in 2014. The Journal of Urmia University of Medical Sciences. 2016;27:729-34.

24. Makan R, Gara M, Awwad MA, Hassona Y. The oral health status of Syrian refugee children in Jordan: An exploratory study. Spec Care Dent. 2019. doi:10.1111/scd.12377.

25. Goodarzi A, Heidarnia A, Tavafian SS, Eslami M. The Survey of Oral-Dental Health of Elementary School Students of Tehran City and its Related Factors. Mil Caring Sci. 2018. doi:10.29252/mcs.5.2.137 [Persian].

26. John JR, Daniel B, Paneerselvam D, Rajendran G. Prevalence of dental caries, oral hygiene knowledge, status, and practices among visually impaired individuals in Chennai, Tamil Nadu. Int J Dent. 2017. doi:10.1155/2017/9419648.

27. Babaee N, Kardan K, Aghazadeh F, Nooribayat S. Effect of oral and dental hygiene education on the knowledge of caries preventive behaviors in the guidance school students. J Babol Univ Med Sci. 2012;14:83-7. [Persian].

28. Sanadhya YK, Thakkar JP, Divakar DD, Pareek S, Rathore K, Yousuf A, et al. Effectiveness of oral health education on knowledge, attitude, practices and oral hygiene status among 12-15-year-old schoolchildren of fishermen of Kutch district, Gujarat, India. International maritime health. 2014. doi:10.5603/IMH.2014.0022.

29. Shirzad M, Taghdisi MH, Dehdari T, Abolghasemi J. Oral health education program among pre-school children: an application of health-promoting schools approach. Health Promot Perspect. 2016. doi:10.15171/hpp.2016.26.

30. Peyman N, Pourhaji F. The effects of educational program based on the Health Belief Model on the oral health behaviors of elementary school students. Mod Care J. 2015;12:74-8.

31. Naseri-Salahshour V, Abredari H, Sajadi M, Sabzaligol M, Karimy M. The effect of oral health promotion program on early dental decay in students: a theory-based study. J Caring Sci. 2019. doi:10.15171/jcs.2019.015.

32. Hajimiri KH, Sharifirad GH, Hasanzade A. The effect of oral health education based on health belief model in mothers who had 3-6year-old children on decreasing dental plaque index in Zanjan. J Adv Med Biomed Res. 2010;18:77-86. [Persian].

33. Shamsi M, Hidarnia A, Niknami S, Rafiee M, Zareban I, Karimy M. The effect of educational program on increasing oral health behavior among pregnant women: Applying health belief model. Health Education Health Promotion. 2014;1(2):21-36.

34. Ghorbani B, Shahnazi H, Hassanzadeh A. Improving student's self-efficacy and perceived susceptibility toward oral and dental health: A randomized controlled trial. Oman Med J. 2018. doi:10.5001/omj.2018.77.

35. Shahnazi H, Hosseintalaei M, Esteki Ghashghaei F, Charkazi A, Yahyavi Y, Sharifirad G. Effect of educational intervention on perceived susceptibility self-efficacy and dmft of pregnant women. Iran red Crescent Med J. 2016. doi:10.5812/ircmj.24960.

36. SohrabiVafa M, Moeini B, Hazavehei MM. Soltanian Ar, rezaei I. The effect of education based on health belief model (HBM) in decreasing dental plaque index among first grade of middle- school girl students in Hamadan. J Urmia Nurs Midwifery Fac. 2013;11(8):639-47. [Persian].

37. Askelson NM, Chi DI, Momany ET, Kuthy rA, Carter KD, Field K, et al. The importance of efficacy: using the extended parallel process model to examine factors related to preschool-age children enrolled in medicaid receiving preventive dental visits. Health Educ Behav. 2015. doi:10.1177/1090198115580575. 
38. Makvandi Z, Karimi-Shahanjarini A, Faradmal J, Bashirian S. Evaluation of an oral health intervention among mothers of young children: A clustered randomized trial. J Res Health Sci. 2015;15:88-93.

39. Levin L, Bilder L, Borisov O. Improving oral hygiene skills among children undergoing treatment at the haemato-oncology department-an interventional programme. Int Dent J. 2015. doi:10.1111/idj.12171.

40. Ebrahimipour S, Ebrahimipoiur H, Alibakhshian F, Mohamadzadeh M. Effect of education based on the theory of planned behavior on adoption of oral health behaviors of pregnant women referred to health centers of Birjand in 2016. J Int Soc Prev Community Dent. 2016. doi:10.4103/2231-0762.195514.

\section{Tables}

Table-1: The characteristics of the tools developed in three areas predisposing, enabling and reinforcing factors 


\begin{tabular}{|c|c|c|c|c|c|c|c|c|c|}
\hline Factor & Structure & $\begin{array}{l}\text { Number } \\
\text { of } \\
\text { questions }\end{array}$ & $\begin{array}{l}\text { Response } \\
\text { scale }\end{array}$ & $\begin{array}{l}\text { How to } \\
\text { respond }\end{array}$ & $\begin{array}{l}\text { The } \\
\text { scope of } \\
\text { questions }\end{array}$ & CVR & CVI & $\begin{array}{l}\text { Cronbach's } \\
\text { alpha }\end{array}$ & $\begin{array}{l}\text { Internal } \\
\text { correlation } \\
\text { coefficient }\end{array}$ \\
\hline & $\begin{array}{l}\text { *Demographic } \\
\text { characteristics }\end{array}$ & 11 & - & $\begin{array}{l}\text { Self- } \\
\text { Reporting }\end{array}$ & - & - & - & - & \\
\hline & Knowledge & 24 & $\begin{array}{l}\text { multiple } \\
\text { choice }\end{array}$ & $\begin{array}{l}\text { Self- } \\
\text { Reporting }\end{array}$ & $0-24$ & 0.95 & 0.96 & - & 0.84 \\
\hline \multirow[t]{7}{*}{$\begin{array}{l}\text { Predisposing } \\
\text { Factors }\end{array}$} & Attitude & 7 & $\begin{array}{l}\text { Three- } \\
\text { part } \\
\text { Likert }\end{array}$ & $\begin{array}{l}\text { Self- } \\
\text { Reporting }\end{array}$ & $7-21$ & 0.94 & 0.97 & 0.72 & \\
\hline & $\begin{array}{l}\text { Perceived } \\
\text { susceptibility }\end{array}$ & 3 & $\begin{array}{l}\text { Three- } \\
\text { part } \\
\text { Likert }\end{array}$ & $\begin{array}{l}\text { Self- } \\
\text { Reporting }\end{array}$ & $3-9$ & 1 & 0.93 & 0.68 & \\
\hline & $\begin{array}{l}\text { Perceived } \\
\text { severity }\end{array}$ & 10 & $\begin{array}{l}\text { Three- } \\
\text { part } \\
\text { Likert }\end{array}$ & $\begin{array}{l}\text { Self- } \\
\text { Reporting }\end{array}$ & $10-30$ & 0.96 & 0.96 & 0.90 & \\
\hline & $\begin{array}{l}\text { Perceived } \\
\text { benefits }\end{array}$ & 11 & $\begin{array}{l}\text { Three- } \\
\text { part } \\
\text { Likert }\end{array}$ & $\begin{array}{l}\text { Self- } \\
\text { Reporting }\end{array}$ & $11-33$ & 1 & 0.99 & 0.78 & \\
\hline & $\begin{array}{l}\text { Subjective } \\
\text { norms }\end{array}$ & 3 & $\begin{array}{l}\text { Three- } \\
\text { part } \\
\text { Likert }\end{array}$ & $\begin{array}{l}\text { Self- } \\
\text { Reporting }\end{array}$ & $3-9$ & 1 & 1 & 0.73 & \\
\hline & $\begin{array}{l}\text { Observational } \\
\text { learning }\end{array}$ & 3 & $\begin{array}{l}\text { Three- } \\
\text { part } \\
\text { Likert }\end{array}$ & $\begin{array}{l}\text { Self- } \\
\text { Reporting }\end{array}$ & $3-9$ & 1 & 1 & 0.85 & \\
\hline & $\begin{array}{l}\text { The } \\
\text { motivation to } \\
\text { comply }\end{array}$ & 3 & $\begin{array}{l}\text { Three- } \\
\text { part } \\
\text { Likert }\end{array}$ & $\begin{array}{l}\text { Self- } \\
\text { Reporting }\end{array}$ & $3-9$ & 1 & 1 & 0.88 & \\
\hline \multirow[t]{5}{*}{$\begin{array}{l}\text { Enabling } \\
\text { Factors }\end{array}$} & $\begin{array}{l}\text { Perceived } \\
\text { barriers }\end{array}$ & 6 & $\begin{array}{l}\text { Three- } \\
\text { part } \\
\text { Likert }\end{array}$ & $\begin{array}{l}\text { Self- } \\
\text { Reporting }\end{array}$ & $6-18$ & 1 & 1 & 0.80 & \\
\hline & Self-efficacy & 5 & $\begin{array}{l}\text { Yes - to } \\
\text { some } \\
\text { extent - } \\
\text { no }\end{array}$ & $\begin{array}{l}\text { Self- } \\
\text { Reporting }\end{array}$ & $5-15$ & 1 & 1 & 0.78 & \\
\hline & $\begin{array}{l}\text { Perceived } \\
\text { behavioral } \\
\text { control }\end{array}$ & 6 & $\begin{array}{l}\text { Yes - to } \\
\text { some } \\
\text { extent - } \\
\text { no }\end{array}$ & $\begin{array}{l}\text { Self- } \\
\text { Reporting }\end{array}$ & $6-18$ & 0.96 & 0.98 & 0.79 & \\
\hline & $\begin{array}{l}\text { Behavioral } \\
\text { preferences }\end{array}$ & 5 & $\begin{array}{l}\text { Three- } \\
\text { part } \\
\text { Likert }\end{array}$ & $\begin{array}{l}\text { Self- } \\
\text { Reporting }\end{array}$ & - & 1 & 1 & - & \\
\hline & Brushing skill & 12 & Yes No & $\begin{array}{l}\text { Checklist- } \\
\text { Observation }\end{array}$ & $0-12$ & - & - & 0.82 & \\
\hline \multirow[t]{5}{*}{$\begin{array}{l}\text { Reinforcing } \\
\text { Factors }\end{array}$} & $\begin{array}{l}\text { Social } \\
\text { reinforcement }\end{array}$ & 5 & $\begin{array}{l}\text { Three- } \\
\text { part } \\
\text { Likert }\end{array}$ & $\begin{array}{l}\text { Self- } \\
\text { Reporting }\end{array}$ & $5-15$ & 1 & 1 & 0.85 & \\
\hline & social support & 4 & $\begin{array}{l}\text { Three- } \\
\text { part } \\
\text { Likert }\end{array}$ & $\begin{array}{l}\text { Self- } \\
\text { Reporting }\end{array}$ & 4-12 & 1 & 1 & 0.76 & \\
\hline & $\begin{array}{l}\text { Behavioral } \\
\text { intention }\end{array}$ & 4 & Yes- No & $\begin{array}{l}\text { Self- } \\
\text { Reporting }\end{array}$ & $0-4$ & 0.95 & 1 & 0.82 & \\
\hline & Behavior & 21 & Yes- No & ${ }^{* *}$ check list- & $0-21$ & - & - & - & \\
\hline & $\begin{array}{l}\text { *Demographic va } \\
\text { status. } * \star \text { Pare }\end{array}$ & $\begin{array}{l}\text { ables includ } \\
\text { ts complete }\end{array}$ & $\begin{array}{l}\text { lage, sex, e } \\
\text { the checklis }\end{array}$ & $\begin{array}{l}\text { ucation, and p } \\
\text { of behavior. }\end{array}$ & 'ents' occup & tion, $f$ & nily inc & me and oral & ealth \\
\hline
\end{tabular}


Table-2: Explaining the Importance of Oral Health, Inappropriate oral health and its impact on quality of life from the perspective of literature review

\begin{tabular}{|ll|}
\hline $\begin{array}{l}\text { Dimensions } \\
\text { of quality of } \\
\text { life }\end{array}$ & Example \\
\hline $\begin{array}{l}\text { Physical } \\
\text { dimension }\end{array}$ & $\begin{array}{l}\text { The incidence of diseases, hallitosis, speech and taste impairment, reduced growth, the risk of malnutrition, sleep } \\
\text { and smile disturbance, impairment in learning, failure to do daily homework, disorder in the game }\end{array}$ \\
\hline $\begin{array}{l}\text { Psychological } \\
\text { dimension }\end{array}$ & $\begin{array}{l}\text { Reduction of self-esteem and self-confidence, incidence of anxiety, stress, depression, feeling restless and chaotic, } \\
\text { dissatisfaction with mental imagery and general appearance, lack of sense of well-being and emotional health, } \\
\text { humiliation feeling, shame and embarrassment }\end{array}$ \\
\hline $\begin{array}{l}\text { Social } \\
\text { dimension }\end{array}$ & $\begin{array}{l}\text { Disruption of communication and social interactions, lack of social participation (like recreational programs), social } \\
\text { rejection and labeling, absence from school and work, disruptions in career and academic performance, impact on } \\
\text { the quality of family life }\end{array}$ \\
\hline $\begin{array}{l}\text { Economic } \\
\text { dimension }\end{array}$ & \begin{tabular}{l} 
Impact on the economic situation of the family, impose economic costs \\
\hline
\end{tabular} \\
\hline
\end{tabular}

Table 3: Behavioral and non-behavioral factors affecting tooth decay based on literature review and scientific resources.

\begin{tabular}{|c|c|}
\hline Behavioral factors & Non-behavioral factors \\
\hline Do not do fluoride therapy & $\begin{array}{l}\text { Person and tooth resistance (genetic factors, congenital or } \\
\text { acquired) }\end{array}$ \\
\hline Use of fluoride-free toothpaste & Fluoride in drinking water \\
\hline No use of dental floss & Age and gender \\
\hline Do not brush & Economic status and social class \\
\hline Over-consumption of sugar, sweets and carbohydrates & Dimensions of the family \\
\hline $\begin{array}{l}\text { Lack of regular referral (six months) to the dentist to receive preventive } \\
\text { services }\end{array}$ & Parent's job and education \\
\hline Overeating and weight gain & blood type \\
\hline Reduce milk and dairy consumption & Level of salivation and concentration \\
\hline \multirow{4}{*}{$\begin{array}{l}\text { Eating snacks and unhealthy snack foods } \\
\text {-chewing Gum, Chips, Puffs, Lavashes and Salt and Nutritional } \\
\text { Snacks- junk food }\end{array}$} & Chronic and systemic diseases \\
\hline & Residence \\
\hline & Consistency of food \\
\hline & Health literacy \\
\hline
\end{tabular}

Table 4: Comparison of the mean score of predisposing, enabling and reinforcing factors before and three months after the intervention in two groups 


\begin{tabular}{|c|c|c|c|c|c|}
\hline \multirow[t]{2}{*}{ Factor } & \multirow[t]{2}{*}{ Structure } & \multirow[t]{2}{*}{ Group } & $\begin{array}{l}\text { Before of } \\
\text { intervention }\end{array}$ & $\begin{array}{l}\text { After of } \\
\text { intervention }\end{array}$ & \multirow[t]{2}{*}{ P-Value* } \\
\hline & & & $\mathrm{M} \pm \mathrm{SD}$ & $\mathrm{M} \pm \mathrm{SD}$ & \\
\hline \multirow{24}{*}{$\begin{array}{l}\text { Predisposing } \\
\text { Factors }\end{array}$} & Knowledge & Intervention & $10.48 \pm 3.37$ & $18.93 \pm 2.77$ & $<0.001$ \\
\hline & \multirow[t]{2}{*}{$(0-24)$} & Control & $10.40 \pm 2.98$ & $11.66 \pm 3.54$ & $<0.001$ \\
\hline & & P-Value** & 0.091 & $<0.001$ & \\
\hline & \multirow{3}{*}{$\begin{array}{l}\text { Attitude } \\
(7-21)\end{array}$} & Intervention & $18.70 \pm 2.00$ & $19.82 \pm 1.99$ & $<0.001$ \\
\hline & & Control & $18.80 \pm 2.01$ & $19.01 \pm 1.81$ & 0.14 \\
\hline & & P-Value** & 0.93 & $<0.001$ & \\
\hline & \multirow{3}{*}{$\begin{array}{l}\text { Perceived Susceptibility } \\
(3-9)\end{array}$} & Intervention & $7.41 \pm 1.45$ & $7.87 \pm 1.40$ & $<0.001$ \\
\hline & & Control & $7.45 \pm 1.49$ & $7.81 \pm 1.27$ & 0.005 \\
\hline & & P-Value & 0.74 & 0.04 & \\
\hline & \multirow{3}{*}{$\begin{array}{l}\text { Perceived } \\
\text { Severity } \\
(10-30)\end{array}$} & Intervention & $24.11 \pm 3.89$ & $28.36 \pm 3.39$ & $<0.001$ \\
\hline & & Control & $23.00 \pm 4.22$ & $23.44 \pm 4.05$ & 0.30 \\
\hline & & P-Value** & 0.05 & $<0.001$ & \\
\hline & \multirow{3}{*}{$\begin{array}{l}\text { Perceived } \\
\text { Benefit } \\
(11-33)\end{array}$} & Intervention & $29.08 \pm 3.35$ & $31.95 \pm 1.96$ & $<0.001$ \\
\hline & & Control & $29.51 \pm 3.24$ & $29.41 \pm 3.21$ & 0.51 \\
\hline & & P-Value** & 0.26 & $<0.001$ & \\
\hline & \multirow{3}{*}{$\begin{array}{l}\text { Subjective Norms } \\
(3-9)\end{array}$} & Intervention & $8.26 \pm 1.07$ & $8.65 \pm 0.83$ & $<0.001$ \\
\hline & & Control & $8.22 \pm 1.19$ & $8.19 \pm 1.20$ & 0.30 \\
\hline & & P-Value** & 0.63 & $<0.001$ & \\
\hline & \multirow{3}{*}{$\begin{array}{l}\text { Motivation to Comply } \\
(3-9)\end{array}$} & Intervention & $7.71 \pm 1.45$ & $8.44 \pm 1.13$ & $<0.001$ \\
\hline & & Control & $7.46 \pm 1.53$ & $7.29 \pm 1.62$ & 0.23 \\
\hline & & P-Value ${ }^{\star \star}$ & 0.11 & $<0.001$ & \\
\hline & \multirow{3}{*}{$\begin{array}{l}\text { Observational Learning } \\
(3-9)\end{array}$} & Intervention & $7.13 \pm 1.89$ & $8.07 \pm 1.63$ & $<0.001$ \\
\hline & & Control & $7.25 \pm 1.57$ & $6.72 \pm 1.86$ & 0.007 \\
\hline & & P-Value** & 0.94 & $<0.001$ & \\
\hline \multirow[t]{12}{*}{ Enabling Factors } & \multirow{3}{*}{$\begin{array}{l}\text { Perceived Barrier } \\
(6-18)\end{array}$} & Intervention & $8.61 \pm 2.29$ & $7.45 \pm 2.33$ & $<0.001$ \\
\hline & & Control & $8.20 \pm 1.94$ & $8.30 \pm 2.82$ & 0.81 \\
\hline & & P-Value** & 0.25 & $<0.001$ & \\
\hline & \multirow{3}{*}{$\begin{array}{l}\text { Self-Efficacy } \\
(5-15)\end{array}$} & Intervention & $13.29 \pm 2.29$ & $14.36 \pm 1.23$ & $<0.001$ \\
\hline & & Control & $13.18 \pm 2.22$ & $13.17 \pm 2.09$ & 0.74 \\
\hline & & P-Value** & 0.49 & $<0.001$ & \\
\hline & \multirow{3}{*}{$\begin{array}{l}\text { Perceived Behavioral Control (6- } \\
\text { 18) }\end{array}$} & Intervention & $14.14 \pm 2.76$ & $16.37 \pm 2.16$ & $<0.001$ \\
\hline & & Control & $14.35 \pm 2.83$ & $14.42 \pm 2.93$ & 0.92 \\
\hline & & P-Value** & 0.49 & $<0.001$ & \\
\hline & \multirow{3}{*}{$\begin{array}{l}\text { Tooth Brushing Skill } \\
(0-12)\end{array}$} & Intervention & $5.72 \pm 2.27$ & $10.72 \pm 1.75$ & $<0.001$ \\
\hline & & Control & $6.44 \pm 2.77$ & $5.59 \pm 2.15$ & 0.01 \\
\hline & & P-Value** & 0.01 & $<0.001$ & \\
\hline
\end{tabular}

Page 12/13 


\begin{tabular}{|c|c|c|c|c|c|}
\hline & & Ancova & - & $<0.001$ & \\
\hline \multirow[t]{7}{*}{ Reinforcing Factors } & \multirow{4}{*}{$(4-12)$} & Intervention & $9.99 \pm 2.12$ & $11.00 \pm 1.61$ & $<0.001$ \\
\hline & & Control & $9.54 \pm 2.06$ & $9.44 \pm 2.35$ & 0.72 \\
\hline & & P-Value** & 0.02 & $<0.001$ & \\
\hline & & Ancova & - & $<0.001$ & \\
\hline & \multirow{3}{*}{$\begin{array}{l}\text { Social Reinforcement } \\
(5-15)\end{array}$} & Intervention & $12.15 \pm 2.76$ & $13.88 \pm 1.85$ & $<0.001$ \\
\hline & & Control & $12.14 \pm 2.47$ & $11.75 \pm 2.92$ & 0.14 \\
\hline & & P-Value** & 0.07 & $<0.001$ & \\
\hline \multirow[t]{4}{*}{ Behavior } & \multirow{4}{*}{$\begin{array}{l}\text { Intention Behavior } \\
(0-4)\end{array}$} & Intervention & $3.19 \pm 1.27$ & $3.73 \pm 0.68$ & $<0.001$ \\
\hline & & Control & $3.74 \pm 0.67$ & $3.33 \pm 1.10$ & 0.62 \\
\hline & & P-Value** & 0.02 & $<0.001$ & \\
\hline & & Ancova & - & $<0.001$ & \\
\hline *Maan Whitny U test & **Wilcoxon test & & & & \\
\hline
\end{tabular}

Table 5: Comparison of frequency distribution of brushing behavior of students before and after intervention in two groups

\begin{tabular}{|c|c|c|c|c|c|c|}
\hline \multirow[t]{2}{*}{ Daily toothbrush behavior } & \multirow[t]{2}{*}{ Group } & \multicolumn{2}{|c|}{ Before intervention } & \multicolumn{2}{|c|}{ After intervention } & \multirow[t]{2}{*}{ P-Value } \\
\hline & & Number & Percentage & Number & Percentage & \\
\hline \multirow[t]{3}{*}{ Less than once } & Intervention & 27 & 22.1 & 1 & 0.82 & $<0.001$ \\
\hline & Control & 16 & 12.5 & 14 & 11.02 & 0.09 \\
\hline & P-Value & 0.03 & & $<0.001$ & & \\
\hline \multirow[t]{3}{*}{ One to two times } & Intervention & 16 & 13.1 & 3 & 2.4 & $<0.001$ \\
\hline & Control & 30 & 23.4 & 27 & 21.2 & 0.08 \\
\hline & P-Value & 0,04 & & $<0.001$ & & \\
\hline \multirow[t]{3}{*}{ Twice and more } & Intervention & 79 & 64.7 & 117 & 96.6 & $<0.001$ \\
\hline & Control & 0.03 & 64 & 86 & 67.6 & 0.08 \\
\hline & P-Value & $<0.001$ & & $<0.001$ & & \\
\hline
\end{tabular}

\section{Supplementary Files}

This is a list of supplementary files associated with this preprint. Click to download.

- AdditionalFile1..docx 